\title{
Phytochemical and Biological Characterization of Aqueous and Ethanolic Extracts of Parthenium hysterophorus
}

\author{
MA Alfaro Jiménez', A Zugasti Cruz², SY Silva Belmares ${ }^{3}$, JA Ascacio Valdés ${ }^{4}$, CA Sierra Rivera ${ }^{5, *}$
}

MA Alfaro Jiménez ${ }^{1}$, A Zugasti

Cruz $^{2}$, SY Silva Belmares ${ }^{3}$, JA

Ascacio Valdés ${ }^{4}$, CA Sierra

Rivera ${ }^{5, *}$

'Master program of Food Science and

Technology, Faculty of Chemistry, Autonomous University of Coahuila, Saltillo, MEXICO.

2Laboratory of Immunology and Toxicology,

Food Research Department, Faculty of

Chemistry, Autonomous University of

Coahuila, Saltillo, MEXICO.

${ }^{3}$ Food Research Department, Faculty of

Chemistry, Autonomous University of

Coahuila, Saltillo, MEXICO.

${ }^{4}$ Bioprocess and Bioproducts Group, Food

Research Department, Faculty of Chemistry,

Autonomous University of Coahuila, Saltillo, MEXICO.

${ }^{5}$ Laboratory of Immunology and Toxicology,

Food Research Department, Faculty of

Chemistry, Autonomous University of

Coahuila, Saltillo, MEXICO.

\section{Correspondence}

\section{CA Sierra Rivera}

Laboratory of Immunology and Toxicology,

Food Research Department, Faculty of

Chemistry, Autonomous University of

Coahuila, Saltillo, MEXICO.

E-mail: crystelsierrarivera@uadec.edu.mx

History

- Submission Date: 31-05-2021;

- Review completed: 29-06-2021;

- Accepted Date: 07-07-2021.

DOI : 10.5530/pj.2021.13.145

Article Available online

http://www.phcogj.com/v13/i5

Copyright

(C) 2021 Phcogi.Com. This is an openaccess article distributed under the terms of the Creative Commons Attribution 4.0 International license.

\begin{abstract}
Introduction: Parthenium hysterophorus is a plant used in traditional medicine to treat health issues and which could be a source of phytochemicals with possible antioxidant activity without causing cytotoxic effects. Hence, this work was designed to evaluate its phytochemical profile, cytotoxicity, and antioxidant activity. Methods: The aqueous (AE) and ethanolic (EE) extracts of $P$. hysterophorus flowers were obtained by decoction and ultrasound, respectively. Their phytochemical composition was determined by colorimetric tests and RP-HPLC-MS analysis. Their cytotoxic activity was tested by a hemolysis assay. The antioxidant activity was evaluated with the Trolox equivalent antioxidant capacity (TEAC), 2,2-diphenyl-1picrylhydrazyl (DPPH), and hydroxyl radical $(-\mathrm{OH})$ scavenging assays. In addition, the effect of the extracts on the activity of the antioxidant enzymes superoxide dismutase (SOD) and catalase (CAT) from human erythrocytes, was evaluated. Results: The phytochemical screening of the AE and EE by colorimetric test showed the presence of flavonoids, steroids, triterpenes, saponins, coumarins, sesquiterpene lactones, tannins, and carbohydrates. In addition, the RP-HPLC-MS analysis identified some phenolic compounds such as flavonols, methoxyflavonols, flavones, methoxyflavones, and hydroxycinnamic acids. The hemolysis assay showed non-cytotoxic activity by $A E$, but EE exhibited a hemolytic effect. Furthermore, the AE and EE showed significant antioxidant activity to inhibit radicals in the TEAC, DPPH and $\mathrm{OH}$ scavenging assays. Moreover, the SOD activity only showed a significant increase by $A E$. However, the two crude extracts increased the CAT activity, at the highest concentrations. Conclusion $P$. hysterophorus has phytochemicals with antioxidant activity to inhibit radicals and increase the activity of antioxidant enzymes in vitro.
\end{abstract}

Key words: Parthenium hysterophorus, Phytochemicals, Cytotoxicity, Antioxidant activity.

\section{INTRODUCTION}

Nowadays, the global population affront diverse health problems, most of them associated with the development of chronic diseases ${ }^{1}$. Cardiovascular illnesses, cancers, respiratory diseases, and diabetes are the main types of diseases responsible for about $70 \%$ of mortality worldwide ${ }^{2}$. It is known the chronic diseases can be developed by the genetic, environmental, and physiological factors that produce diverse negative effects in the organism. One of them is the oxidative stress ${ }^{3}$

The oxidative stress is a phenomenon produced by an excessive production of free radicals in the organism that causes cytotoxic effects that can alter the functions of tissues and organs and which can induce the development of chronic diseases". Reactive oxygen species (ROS) constitute a type of free radicals that contain oxygen as main element in their chemical structure such as hydroxyl radical $(-\mathrm{OH})$, superoxide anion $\left(\mathrm{O}_{2}^{-}\right)$, and hydrogen peroxide $\left(\mathrm{H}_{2} \mathrm{O}_{2}\right)$ and which are mainly responsible for oxidative stress ${ }^{5}$.

For this, the human body has antioxidant mechanisms to regulate the oxidative stress which are based on the inhibition of ROS by diverse compounds and enzymes such as superoxide dismutase (SOD), and catalase (CAT) ${ }^{6}$. However, the influence of genetic, environmental, and biological factors can induce an overproduction of ROS causing an imbalance between ROS production and antioxidant activity, causing the oxidative stress and increasing the risk of developing chronic diseases ${ }^{5}$.

Therefore, it is vitally important to obtain compounds from natural sources without adverse effects on the organism that can contribute to the prevention of diseases through the inhibition of the ROS and the stimulation of the activity of antioxidant enzymes.

For a long time, plants have been used as traditional treatments for diverse health issues. Their medicinal properties are associated with the presence of phytochemical compounds such as flavonoids, steroids, triterpenes, coumarins, sesquiterpene lactones, tannins, alkaloids, and carbohydrates, which have demonstrated diverse biological activities, including antioxidant activity ${ }^{7-8}$. These phytochemicals can be recovered from plants through different methods of extraction which are classified in traditional and nonconventional methods 9 . Some traditional methods are decoction, maceration, filtration, and Soxhlet extraction. Among these methods, the decoction is an extraction procedure famous for being used in herbal medicines for the recovering of watersoluble and thermostable metabolites with several biological activities including antioxidant activity. In this procedure, the phytochemicals are extracted from plant material dissolved in an aqueous solution in which heat is applied until boiling point. On the other hand, the non-conventional methods involve other procedures such as the ultrasound and microwave-assisted extraction, and supercritical fluid extraction ${ }^{10}$. Among the non-conventional 
methods, the ultrasound-assisted extraction is known to be a valuable technique due to its capacity to extract bioactive compounds within short extraction times. Moreover, it has a low energy consumption, and exhibits high extraction yields compared to some traditional extraction methods ${ }^{11}$. Therefore, in recent years the extraction by ultrasound has become an important method for the recovery of bioactive compounds.

In the decoction and ultrasound-assisted extraction it is required the use of solvents for the recovery of phytochemicals. The solvents have the function of dissolving those compounds with similar polarity, which produces the separation of the phytochemicals from inert plant material ${ }^{12}$. Among the different solvents that are employed, the water and ethanol are polar solvents commonly used in the procedures of extraction due to these have demonstrated to recover phenolic compounds from plant matrices, which are metabolites with a wide variety of biological properties, including the antioxidant activity ${ }^{13}$.

In addition, the water and ethanol exhibit low toxicity compared to other solvents such as hexane, benzene, ethyl acetate, and chloroform, this according to the safety criteria for health and environment stablished by different international solvent selection guides ${ }^{14-15}$.

Currently, there is a wide variety of plant species known to be used in the traditional medicine and which could be subjected to extraction procedures to recover bioactive compounds with antioxidant activity. One of them is Parthenium hysterophorus, also known as parthenium weed, altamisa, carrot grass, bitterweed and wild feverfew, which is an annual herbaceous shrub belonged to the Asteraceae family ${ }^{16}$. $P$. hysterophorus is native of north-east Mexico but also spread in America, Asia, Australia and Africa ${ }^{17-18}$. It adapts to a variety of climatic and environmental conditions and can be found in roadsides, rock crevices and around the towns ${ }^{16}$.

In traditional medicine, the decoction of $P$. hysterophorus plant has been used to treat health issues such as wounds, fever, anemia, inflammatory skins, neural diseases, and female reproductive problems ${ }^{19}$. These medicinal uses have exhibited the importance of studying the phytochemical composition of extracts obtained from the different parts of this plant, including their flowers. It has been reported the phytochemical composition of extracts from the flowers of $P$. hysterophorus which include the presence of diverse phytochemical groups such as flavonoids, terpenes, and sesquiterpene lactones. In addition, these extracts have showed biological properties such as antitumor, antibacterial, and antioxidant activity ${ }^{17,20-21}$. Although some authors have evaluated the biological potential of $P$. hysterohorus for human health, most of these studies have been performed on $P$. hysterophorus plants growth in India, using Soxhlet extraction and different organic solvents in addition to water and ethanol ${ }^{17-19,21}$, but there is few information about the biological properties of plants of $P$. hysterophorus found in Mexico in which this species is native.

For the above, the aim of this work was to determine the phytochemical composition, cytotoxic and antioxidant activity of aqueous and ethanolic crude extracts of flowers of $P$. hysterophorus, obtained by the methods of decoction and ultrasound-assisted extraction, respectively.

\section{MATERIAL AND METHODS}

\section{Plant material}

The $P$. hysterophorus plants were collected in Saltillo, Coahuila, Mexico at the coordinates $25^{\circ} 26^{\prime} 29.6^{\prime \prime} \mathrm{N}, 100^{\circ} 59^{\prime} 06.6^{\prime \prime} \mathrm{W}$ during August 2019. The plant specimen was identified taxonomically by Dr. José Ángel Villarreal Quintanilla, and specimens were preserved in the herbarium of the Antonio Narro Agrarian Autonomous University (UAAAN) with the registry number 101810. Subsequently, flowers were washed with deionized water, dried by lyophilization (Labconco FreeZone 1
Liter Benchtop Freeze Dry System) and stored at $-80{ }^{\circ} \mathrm{C}$ until to be used.

\section{EXTRACTION}

\section{Aqueous crude extract}

To obtain the aqueous crude extract (AE) the methodology was performed according to Georgervia et. al ${ }^{22}$ with some modifications. Flowers $(140 \mathrm{~g})$ were immersed in $\mathrm{H}_{2} \mathrm{O}$ to a proportion of $10 \%$ weight of extract/volume of solvent $(\mathrm{w} / \mathrm{v})$ in Erlenmeyer flasks which were incubated at $4{ }^{\circ} \mathrm{C}$ for $90 \mathrm{~h}$. Thereafter, flasks were heated until ebullition and maintained for $15 \mathrm{~min}$. Then, flasks were incubated again at $4{ }^{\circ} \mathrm{C}$ for $48 \mathrm{~h}$. Subsequently, the suspension was filtered with Whatman filters No. $4(20 \mu \mathrm{m})$ and concentrated to dryness by lyophilization for $72 \mathrm{~h}$, obtaining the AE.

\section{Ethanolic crude extract}

The ethanolic crude extract (EE) was performed according to the methodology established by Chen et. al ${ }^{23}$ with some modifications. Flowers $(137 \mathrm{~g})$ were ground and immersed in ethanol $96^{\circ}$ to a proportion of $5 \%(\mathrm{w} / \mathrm{v})$ in Erlenmeyer flasks which were placed in ultrasound equipment (BRANSON 3800, $40 \mathrm{kHz}$ ) for $30 \mathrm{~min}$ at room temperature. Then, ethanolic suspension was filtered with Whatman filters No. $4(20 \mu \mathrm{m})$ and clarified using Whatman filters GF/A (1.6 $\mu \mathrm{m})$. The solvent was eliminated by evaporation in a rotary evaporator (Büchi Re 120) coupled to a recirculatory system (Lauda Alpha Ra 8) under reduced pressure $(20 \mathrm{psi})$ at $45^{\circ} \mathrm{C}$, obtaining the dried crude ethanolic extract (EE).

The yield percentages ( $\mathrm{Y} \%$ ) in both $\mathrm{AE}$ and $\mathrm{EE}$ were determined with the following formula:

$$
\boldsymbol{Y} \%=\frac{\text { Recovered mass }}{\text { Initial mass }} \times 100
$$

The aqueous and ethanolic crude extracts were stored at $-20^{\circ} \mathrm{C}$ until use.

\section{PHYTOCHEMICAL SCREENING BY COLORIMET- RIC METHODS}

\section{Colorimetric test}

The phytochemical analysis of $\mathrm{AE}$ and $\mathrm{EE}$ were carried out using qualitative colorimetric standard methods ${ }^{24-25}$. Two solutions of the $\mathrm{AE}$ and $\mathrm{EE}(2 \mathrm{mg} / \mathrm{mL})$ were employed to identify the presence of flavonoids, steroids, triterpenes, phytosterols, coumarins, sesquiterpene lactones, tannins, alkaloids, and carbohydrates. Moreover, the presence of unsaturations (double bonds) and phenolic oxyhydriles were evaluated. These are constituents of the chemical structure of many phytochemicals such as flavonoids, and which determines the antioxidant activity of these compounds.

\section{Test for flavonoids}

Sulfuric acid test: For the test, $20 \mu \mathrm{L}$ of sulfuric acid concentrated was added in $100 \mu \mathrm{L}$ of sample. The test is positive if occurs the appearance of yellow-orange colors for flavonoids and red-blue colors for chalcones and aurones.

\section{Test for steroids}

Modified Liebermann-Burchard test: This test consisted in adding 20 $\mu \mathrm{L}$ of Liebermann-Burchard's reagent in $100 \mu \mathrm{L}$ of sample. The test is positive for the presence of steroids if occurs the appearance of blue or green colors. 


\section{Test for phytosterols and triterpenes}

Salkowski's test: To perform this test, $20 \mu \mathrm{L}$ of chloroform and sulfuric acid concentrated were added in $100 \mu \mathrm{L}$ of sample. The test is positive for phytosterols if occurs the appearance of red-brown colors. On the other hand, yellow color indicates the presence of triterpenes.

\section{Test for saponins}

Foam test: The test was performed dissolving $2 \mathrm{mg}$ of sample in $1 \mathrm{~mL}$ of $\mathrm{H}_{2} \mathrm{O}$. Subsequently, the mixture was shaken vigorously for $1 \mathrm{~min}$. The test is positive if occurs the formation of a foamy lather in the top of the tube.

\section{Test for coumarins}

Sodium hydroxide $10 \%$ test: The test consisted in adding $20 \mu \mathrm{L}$ of a sodium hydroxide solution $10 \%(\mathrm{w} / \mathrm{v})$ in $100 \mu \mathrm{L}$ of sample. Then, 20 $\mu \mathrm{L}$ of hydrochloric acid concentrated was added. The test is positive if occurs a discoloration of the solution when it is acidulated.

\section{Test for sesquiterpenlactones}

Baljet's test: The test was performed dissolving $20 \mu \mathrm{L}$ of Baljet's reagent (picric acid + sodium hydroxide) in $100 \mu \mathrm{L}$ of sample. The test is positive for the appearance of orange or red colors.

\section{Test for tannins}

Ferric chloride test: The presence of tannins was evaluated by the addition of $50 \mu \mathrm{L}$ of ferric chloride solution $2.5 \%(\mathrm{w} / \mathrm{v})$ in $100 \mu \mathrm{L}$ of sample. The test is positive for the appearance of a blue color.

\section{Test for alkaloids}

Dragendorff's test: To perform this test, $20 \mu \mathrm{L}$ of Dragendorff's reagent (potassium iodide + bismuthyl nitrate) was added in $100 \mu \mathrm{L}$ of sample. The test is positive if occurs the formation of a reddish-brown precipitate for $24 \mathrm{~h}$.

Wagner's test: The test was performed by the addition of $20 \mu \mathrm{L}$ of Wagner's reagent (iodine + potassium iodide) and hydrochloric acid concentrated in $100 \mu \mathrm{L}$ of sample. The test is positive for the appearance of a flocculent brown precipitate.

Mayer's test: The test consisted in adding $60 \mu \mathrm{L}$ of Mayer's reagent (mercuric chloride + potassium iodide) in $300 \mu \mathrm{L}$ of sample. The test is positive for the appearance of a white precipitate.

\section{Test for carbohydrates}

Molisch's test: The presence of carbohydrates was determined by the addition of $60 \mu \mathrm{L}$ of Molish's reagent ( $\square$-Naphthol) and sulfuric acid concentrated in $300 \mu \mathrm{L}$ of sample. The test is positive for the appearance of violet ring located in the interphase

\section{Test for unsaturations}

Potassium permanganate test: Unsaturations were evaluated by dissolving $20 \mu \mathrm{L}$ of potassium permanganate solution $2 \%(\mathrm{w} / \mathrm{v})$ in $100 \mu \mathrm{L}$ of sample. The test is positive for the appearance of a brown precipitate.

\section{Test for phenolic oxyhydriles}

Ferric chloride test: For this test, $50 \mu \mathrm{L}$ of a ferric chloride solution 2.5 $\%(\mathrm{w} / \mathrm{v})$ was added in $100 \mu \mathrm{L}$ of sample. The test is positive for the appearance of red, blue, violet or green colors.

Phytochemical screening by Reverse-phase high performance liquid chromatography/mass spectrometry (RP-HPLC-MS)
The phenolic phytochemical profiles of $\mathrm{AE}$ and EE were also evaluated by RP-HPLC-MS, according to De León-Medina et. $a{ }^{26}$. The chromatographic analysis was carried out on a Varian HPLC system, including an autosampler (VarianProStar 410, Palo Alto, CA, USA), a ternary pump (VarianProStar 230I, Palo Alto, CA, USA) and a photo diode array (PDA) detector (VarianProStar 330, Palo Alto, CA, USA). A liquid chromatograph ion trap mass spectrometer (Varian 500MS IT Mass Spectrometer, Palo Alto, CA, USA) equipped with an electrospray ion source also was used. Samples $(5 \mu \mathrm{L})$ were injected onto a Denali C18 column $(150 \times 2.1 \mathrm{~mm}, 3 \mu \mathrm{m}$, Grace, Palo Alto, CA, USA). The oven temperature was maintained at $30^{\circ} \mathrm{C}$. The eluents were formic acid $(0.2 \%, \mathrm{v} / \mathrm{v}$; solvent $\mathrm{A})$ and acetonitrile (solvent $\mathrm{B}$ ). The following gradient was applied: initial, $3 \% \mathrm{~B} ; 0-5 \mathrm{~min}, 9 \% \mathrm{~B}$ linear; 5-15 min, 16\% B linear; 15-45 min, 50\% B linear. The column was then washed and reconditioned. The flow rate was maintained at 0.2 $\mathrm{mL} / \mathrm{min}$, and elution was monitored at 245, 280, 320 and $550 \mathrm{~nm}$. The whole effluent $(0.2 \mathrm{~mL} / \mathrm{min})$ was injected into the source of the mass spectrometer, without splitting. All MS experiments were carried out in the negative mode $[\mathrm{M}-\mathrm{H}]^{-1}$. Nitrogen was used as nebulizing gas and helium as damping gas. The ion source parameters were: spray voltage $5.0 \mathrm{kV}$, and capillary voltage and temperature were $90.0 \mathrm{~V}$ and $350{ }^{\circ} \mathrm{C}$, respectively. Data were collected and processed using MS Workstation software (V 6.9). Samples were firstly analyzed in full scan mode acquired in the $\mathrm{m} / \mathrm{z}$ range $50-2000$.

\section{Cytotoxicity assay in vitro}

The cytotoxicity activity of AE and EE was determined through a hemolysis assay according to the methodology of Macías-Martínez et. $a l^{27}$ and Zugasti et. $a l^{28}$. The present study was approved by the Ethics Committee (Approval code: 27-2020) of Faculty of Chemistry, Autonomous University of Coahuila, Mexico. The hemolysis assay was performed using human whole blood from healthy donors who signed an informed consent form. In briefly, human blood samples were obtained in heparin tubes. The blood was centrifugated at 3200 rpm for $4 \mathrm{~min}$ at $4^{\circ} \mathrm{C}$, plasma was discarded, and erythrocyte pellet was washed three times with Alsever's solution. Thereafter, an erythrocyte suspension was prepared in Alsever's solution (1:100) and distributed in a 24-well culture plates. Erythrocytes were treated with $\mathrm{AE}$ and $\mathrm{EE}$ $(200-800 \mu \mathrm{g} / \mathrm{mL})$. Moreover, ascorbic acid (Asc-A) and resveratrol (Resv), were employed as references, at concentrations of $13.2 \mu \mathrm{g} / \mathrm{mL}$ and $22.8 \mu \mathrm{g} / \mathrm{mL}$, respectively. Subsequently, plates were incubated $\left(37^{\circ} \mathrm{C}\right.$ for $\left.1 \mathrm{~h}\right)$. After incubation, cells were collected, centrifugated under $2500 \mathrm{rpm}$ for $10 \mathrm{~min}$ and supernatants were used to measure absorbances of released hemoglobin at $415 \mathrm{~nm}$. Two controls were employed: a negative control (C-) without treatment, and a positive control $(\mathrm{C}+)$ constituted by erythrocytes treated with distilled $\mathrm{H}_{2} \mathrm{O}$ to produce total hemolysis. Hemolysis percentage (Hemolysis \%) was calculated with the following formula:

$$
\text { Hemolysis \% }=\left[\frac{\left(A_{\mathrm{t}}-A_{n}\right)}{\left(A_{p}-A_{n}\right)}\right] \times 100
$$

Where:

$A_{\mathrm{t}}$ : Test sample absorbance

$A_{n}$ : Negative control absorbance

$A_{p}$ : Positive control absorbance

\section{RADICAL SCAVENGING ANTIOXIDANT ASSAYS}

\section{Trolox equivalent antioxidant capacity (TEAC)}

The TEAC assay was performed employing Antioxidant Assay Kit from Cayman Chemicals (USA) (Item No. 709001), and following manufacturer's instructions. In this assay, $10 \mu \mathrm{L}$ of $\mathrm{AE}$ and $\mathrm{EE}(1000$ 
$\mu \mathrm{g} / \mathrm{mL}), 10 \mu \mathrm{L}$ metmyoglobin, and $150 \mu \mathrm{L}$ ABTS (2,2'-azino-bis [3-ethylbenzothiazoline-6-sulfonic acid]) were added per well in a 96well culture plateau. Then, reaction was initiated by adding $40 \mu \mathrm{L} \mathrm{H}_{2} \mathrm{O}_{2}$ $(441 \mu \mathrm{M})$. Plateau was incubated on a shaker for 5 minutes at $25^{\circ} \mathrm{C}$, and absorbances were measured at $750 \mathrm{~nm}$ in a plate reader. Asc-A and Resv $(1000 \mu \mathrm{g} / \mathrm{mL})$, were used as standard references. Antioxidant activity was calculated by linear regression in a Trolox standard curve $(0.068-0.495 \mathrm{mM}$ Trolox $)$. Results were expressed as the antioxidant activity of a millimolar concentration of Trolox that is equivalent to the antioxidant activity of $1 \mathrm{mg}$ of sample $(\mathrm{mM} / \mathrm{mg})$.

\section{2,2-diphenyl-1-picrylhydrazyl (DPPH) assay}

The DPPH radical scavenging activity of AE and EE was determined according to Arituluk et. a $^{29}$. For this assay, DPPH radical solution (1 $\mathrm{mM}$ ) was prepared in $\mathrm{EtOH}$. Subsequently, $50 \mu \mathrm{L}$ of this solution was added in $150 \mu \mathrm{L}$ of $\mathrm{AE}$ and $\mathrm{EE}(200-800 \mu \mathrm{g} / \mathrm{mL})$. Resv and Asc-A $(200-800 \mu \mathrm{g} / \mathrm{mL})$ were used as standard references. The mixtures were incubated for 30 minutes (darkness, $25^{\circ} \mathrm{C}$ ), and absorbance was measured at $517 \mathrm{~nm}$. Radical scavenging activity was expressed as the inhibition percentage of DPPH radical (DPPH Inhibition \%) and calculated with the following formula:

DPPH Inhibition $\%=\left[\frac{\left(A_{\text {blank }}-A_{\text {sample })}\right.}{A_{\text {blank }}}\right] \times 100$

Where:

A blank : Absorbance of blank

Asample: Absorbance of sample

Hydroxyl $(-\mathrm{OH})$ radical scavenging activity

Hydroxyl radical scavenging capacity of AE and EE was determined according to Ozyurek et. $a l^{30}$. In this assay, reacting mixtures constituted by $200 \mu \mathrm{L} \mathrm{KH}_{2} \mathrm{PO}_{4}-\mathrm{KOH}(100 \mathrm{mM}), 200 \mu \mathrm{L} \mathrm{FeCl}_{3}(500$ $\mu \mathrm{M}), 100 \mu \mathrm{L} \operatorname{EDTA}(1 \mathrm{mM}), 100 \mu \mathrm{L}$ Asc-A $(1 \mathrm{mM}), 100 \mu \mathrm{L} \mathrm{H}_{2} \mathrm{O}_{2}, 100$ $\mu \mathrm{L}$ sample $(200-800 \mu \mathrm{g} / \mathrm{mL})$, and $200 \mu \mathrm{L}$ deoxyribose $(15 \mathrm{mM})$ were added in assay tubes and incubated at $37^{\circ} \mathrm{C}$ for $1 \mathrm{~h}$. Thereafter, $1 \mathrm{~mL}$ of trichloroacetic acid $(1 \% \mathrm{w} / \mathrm{v})$ was added and tubes were centrifugated at $5000 \mathrm{rpm}$ for $15 \mathrm{~min}$. After centrifugation, $1 \mathrm{~mL}$ of thiobarbituric acid $(2.8 \% \mathrm{w} / \mathrm{v})$ was added and tubes were incubated in a water bath at $80-90{ }^{\circ} \mathrm{C}$ for $15 \mathrm{~min}$. Subsequently, tubes were cooled in ice and mixtures were distributed in a 24 -well culture plateau $(1 \mathrm{~mL}$ per well). Finally, absorbances were measured at $532 \mathrm{~nm}$. Asc-A and Resv (200 - $800 \mu \mathrm{g} / \mathrm{mL}$ ) were used as standard references. Moreover, a blank (extract substituted with $\mathrm{H}_{2} \mathrm{O}$ ) and a sample blank (extract added but without deoxyribose) were employed. The $\mathrm{OH}$ inhibitory activity $(-\mathrm{OH}$ inhibition \%) was determined using the following activity:

OH Inhibition $\%=\left[\frac{\left(A_{\text {blank }}-\left(A_{\text {sample }}-A_{\text {sample blank }}\right)\right.}{A_{\text {blank }}}\right] \times 100$

Where:

Ablank: Absorbance of blank

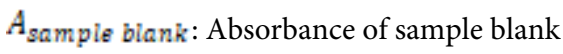

$A_{\text {sample }}$ : Absorbance of sample

\section{Antioxidant enzymatic activity}

Supernatants of erythrocytes previously treated with the AE, EE, and standard references for hemolysis assay, were collected and employed for the following antioxidant enzymatic assays.

\section{Superoxide dismutase (SOD) activity}

The assay was performed employing the Superoxide Dismutase Assay Kit from Cayman Chemicals (USA) (Item No. 706002), and following manufacturer's instructions. Briefly, supernatants were diluted with sample buffer (1:100). Subsequently, $10 \mu \mathrm{L}$ samples were added with $200 \mu \mathrm{L}$ diluted radical detector in each well of a 96-well culture plateau. Then, reaction was initiated by adding $20 \mu \mathrm{L}$ xanthine oxidase and plateau was incubated on a shaker for $30 \mathrm{~min}$ at $25^{\circ} \mathrm{C}$. Absorbances were measured at $440 \mathrm{~nm}$ in a plate reader. A standard curve of bovine erythrocyte SOD $(0.005-0.050 \mathrm{U} / \mathrm{mL})$ was performed to determine the SOD activity of samples which were calculated with the following formula:

$\operatorname{SOD}(\mathrm{U} / \mathrm{mL})=\left[\left(\frac{\text { Sample LR }-\mathrm{y} \text { intercept }}{\text { slope }}\right) \times \frac{0.23 \mathrm{~mL}}{0.01 \mathrm{~mL}}\right] \mathrm{x}$ sample dilution

One unit is defined as the amount of SOD enzyme required to exhibit $50 \%$ dismutation of $\mathrm{O}_{2}^{-}$radical.

\section{Catalase (CAT) activity}

The assay was performed using Catalase Assay Kit from Cayman Chemicals (USA) (Item No. 707002), and following manufacturer's instructions. For this assay, supernatants were diluted with sample buffer (1:25). Subsequently, $100 \mu \mathrm{L}$ assay buffer, $30 \mu \mathrm{L}$ methanol, and $20 \mu \mathrm{L}$ sample were added per well in a 96-well culture plateau. Then, reaction was initiated by adding $20 \mu \mathrm{L} \mathrm{H}_{2} \mathrm{O}_{2}(35.3 \mathrm{mM})$ and plateau was incubated on a shaker for $20 \mathrm{~min}$ at $25^{\circ} \mathrm{C}$. Absorbances were measured at $540 \mathrm{~nm}$ in a plate reader. A standard curve of formaldehyde (5 - 75 $\mu \mathrm{M}$ ) was performed to determine the CAT activity of samples which were calculated with the following formula:

CAT $(\mathrm{nmol} / \mathrm{min} / \mathrm{mL})=\left(\frac{\mu M \text { of sample }}{20 \mathrm{~min}}\right) x$ sample dilution

One unit is defined as the amount of CAT needed to produce $1.0 \mathrm{nmol}$ of formaldehyde per minute at $25^{\circ} \mathrm{C}$.

\section{Statistical analysis}

The hemolytic assay was performed in triplicate while antioxidant assays were performed at least twice. The sample means were compared by one-way ANOVA followed by Dunnett's Multiple Comparison Test, using the SPSS 16.0 statistical software. Differences between means at $95 \%$ confidence level $\left({ }^{\star} p<0.05\right)$ were considerate as statistically significant.

\section{RESULTS AND DISCUSSION}

\section{Yield percentages and phytochemical characterization}

$P$. hysterophorus is a plant known to be employed in the traditional medicine due to its pharmacological properties that could be associated with the activity of phytochemicals which can be recovered through the obtention of extracts. Previous studies have evaluated the biological properties of $P$. hysterophorus, including its antioxidant activity. However, most of these studies have employed plants collected in Asiatic countries, mainly in India where Parthenium has become popular due to its medicinal uses ${ }^{19,21,31}$. However, there is few information about the biological potential of the varieties of $P$. hysterophorus found in the north-east Mexico where it is native. It is known the geographic distribution and the influence of environmental factors of each region such as light, temperature, soil water fertility can produce differences in phytochemical profile and biological activities of plants even in 
those belonged to the same species ${ }^{32}$. Therefore, it was of interest to evaluate the phytochemical composition of $P$. hysterohorus plants collected in the north region of Mexico and determine their cytotoxic and antioxidant activity.

In this study, the AE and EE were obtained by decoction and ultrasound, respectively. The method of decoction was employed for the extraction of AE due to this is a common type of preparation of the P. hysterophorus plants in the traditional medicine ${ }^{19}$. Since, it was considerate important to study the compounds that can be obtained through this traditional extraction procedure and their biological activities. On the other hand, the ultrasound-assisted extraction was used for the obtention of the EE due to previous studies have demonstrated that the combination of ultrasound and ethanol for the extraction of metabolites from plants produce higher yields and bioactivity than the extracts obtained by other traditional methods ${ }^{9,11}$.

The results of this work exhibited that the AE and EE obtained Y \% values of $9.08 \%$ and $11.51 \%$, respectively, being the yield of the $\mathrm{EE}$ a slightly higher than the $\mathrm{AE}$ (Table 1). Regarding to these results, it has been reported that the yield of plant extracts is associated with the applied solvents, and extraction methods ${ }^{33}$. In this context, the ultrasound-assisted extraction could have produced a higher yield than decoction due to the application of ultrasound waves on plant material that produces the disruption of cell walls and the release of more metabolites which were subsequently dissolved in the ethanol ${ }^{34}$. On the other hand, in the decoction method the plant material is boiled to recover water-soluble compounds found in the plant. However, the application of high temperatures in this procedure can produce the degradation of some thermolabile or volatile metabolites, reducing the number of compounds that can be recovered and decreasing the yields ${ }^{35}$.

Furthermore, these results obtained in our work are higher than other yields of Parthenium plant extracts previously reported by other authors and which were obtained by different extraction methods. Das et. $a l^{20}$ reported to obtain an extract from flowers of $P$. hysterophorus by maceration, employing a solvent combination of dichloromethane - methanol, and obtaining a yield of $1.65 \%$. Moreover, HernándezMarín et. $a l^{36}$ obtained extracts from leaves and barks of Parthenium incanum, by Soxhlet extraction, using chloroform, methanol, and hexane, with yields of $2.51 \%, 8.05 \%$, and $2.54 \%$, respectively.

On the other hand, the phytochemical colorimetric analysis (Figure 1) showed that the AE and EE from the flowers of P.hysterophorus contain flavonoids, triterpenes, coumarins, sesquiterpene lactones, carbohydrates, tannins but alkaloids and phytosterols were not found. On the other hand, steroids and saponins were only detected in EE.

Table 1: Phytochemical profile and yield percentages of AE and EE of $P$. hysterophorus.

\begin{tabular}{lcc}
\hline \multirow{2}{*}{ Phytochemical groups } & \multicolumn{2}{c}{ Extracts } \\
\cline { 2 - 3 } Flavonoids & $\mathrm{AE}$ & $\mathrm{EE}$ \\
Steroids & + & + \\
Phytosterols & - & + \\
Triterpenes & + & - \\
Saponins & - & + \\
Coumarins & + & + \\
Sesquiterpene lactones & + & + \\
Tannins & + & + \\
Alkaloids & - & + \\
Carbohydrates & + & - \\
Unsaturations & + & + \\
Phenolic oxyhydriles & + & + \\
Yield \% & $9.08 \%$ & + \\
\hline
\end{tabular}

+ : present; - : absent
These groups of metabolites have been previously reported in extracts from leaves, flowers, and roots of $P$. hysterophorus ${ }^{6,19}$. Among these phytochemical families, sesquiterpene lactones constitute a group of metabolites commonly found in extracts of other species of the genus Parthenium. Previous studies have reported the presence of these compounds in ethanol/ethyl acetate extract from leaves of $P$. hispitum $^{20}$, and acetone and hexane extracts from derubberized resin of $P$. argentatum ${ }^{21}$. The colorimetric tests also showed the presence of unsaturations and phenolic oxyhydriles in the AE and EE (Table 1). These elements are known to be part of the chemical structure of different metabolites, such as phenolic compounds. Previous studies have exhibited the presence and position of double bonds and oxyhydril groups in the molecules of phenolic metabolites have an influence in their antioxidant activity ${ }^{37}$.

In addition, the RP-HPLC-MS analysis showed a total of ten and twelve phenolic compounds in $\mathrm{AE}$ and $\mathrm{EE}$, respectively. The differences about the phytochemical profile of the $\mathrm{AE}$ and $\mathrm{EE}$ can be associated with the polarity of the water and ethanol used as solvents which could have extracted selectively these metabolites from the plant material ${ }^{38}$. The AE showed the presence of metabolites belonged to different phytochemical families such as flavonols, methoxyflavonols, flavones, methoxyflavones, and hydroxycinnamic acids. It is known the water is a solvent with the capacity to dissolve compounds with high polarity ${ }^{39}$. In this case, the metabolites found in the AE are phenolic compounds whose chemical structure contains hydroxyl and ketone groups which causes a strong polarity in these molecules that makes them affine to the high polarity of water ${ }^{38}$. Moreover, various glycoside compounds such as caffeic acid 4-O-glucoside, isorhamnetin 3-O-glucoside, isorhamnetin 4'-O-glucoside, and luteolin 7-O-(2-apiosyl-6-malonyl)glucoside were found in the AE. It is known the linkage between phenolic compounds a glucosyl molecules can increase the solubility of these metabolites in aqueous solutions and allows them to be recovered during the extraction processes ${ }^{40}$.

On the other hand, the EE also exhibited the presence of compounds belonged to flavonols, flavones and derivatives. However, these metabolites were not the same than those found in the AE. In addition, more compounds belonged to different families such as phenolic terpenes, ellagitannins, lignans, and hydroxybenzoic acids were also identified. It has been reported that phenolic compounds such as flavonoids and phenolic acids also exhibit affinity for other solvents such as ethanol ${ }^{41}$. For this reason, these compounds could also be detected in the EE. Moreover, the differences in the phytochemical profile of the EE could be attributed to various factors. One of them is the lower polarity of ethanol than water, which produces that only some specific compounds with similar polarity could be recovered through this solvent (Table 2) ${ }^{42}$.

According to previous studies published by other authors, some of the phenolic compounds identified in the $\mathrm{AE}$ and $\mathrm{EE}$ of $P$. hysterophorus have also been detected in extracts from other plants. The hydroxycinnamic acids are known for being part of phytochemical profile of Asteraceae plants ${ }^{43}$. Some the identified compounds in this work such as 1-caffeoylquinic acid, 3-caffeoylquinic acid, and 1,3-dicaffeoylquinic acid, have also been detected in methanolic leaf extracts of other Asteraceae plants including Cichorium intybus, Inula helenium, Artemesia drancunculus, Echinops humilis, and Tanacetum parthenium $^{44}$. Moreover, methoxyflavonols such as isorhamnetin derivatives have been reported in methanolic extracts from aerial parts of Chuquiraga spinosa $a^{45}$. Other compounds such as cirsimaritin, 4-hydroxybenzoic acid, and protocatechuic acid have been reported in extracts of Centaurea kilae ${ }^{46}$, Hieracium pilosella ${ }^{47}$, and Erigeron $a_{c r i s}{ }^{48}$, respectively, while ellagitanins $s^{49}$, and spinacetin derivatives have also been detected in extracts of Fluorencia cernua and Gnaphalium uliginodum, respectively ${ }^{50}$. 


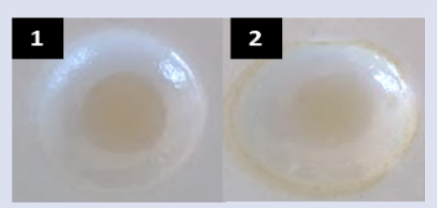

A)

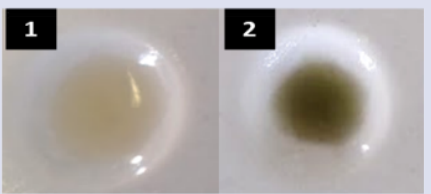

C)

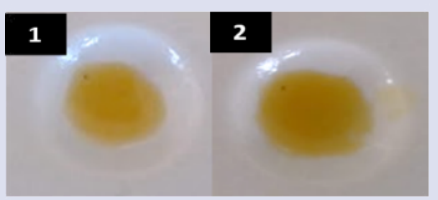

E)

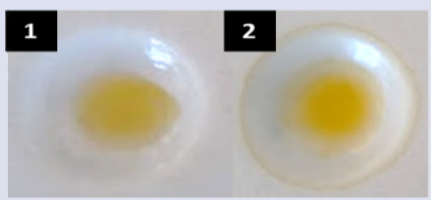

B)

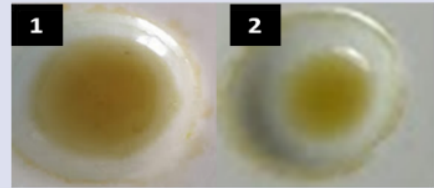

D)

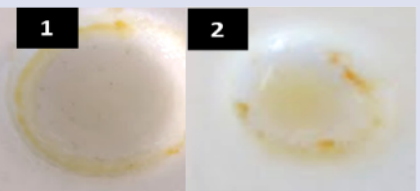

F)

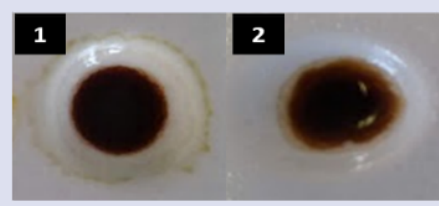

G)

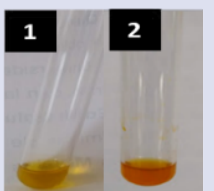

I)

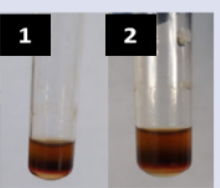

L)

J)

M)

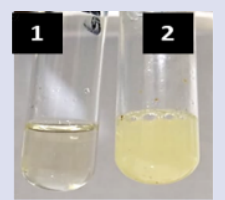

H)
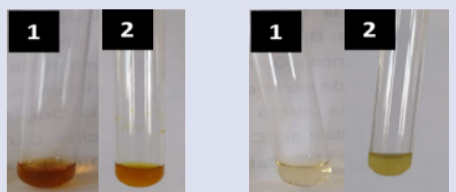

K)

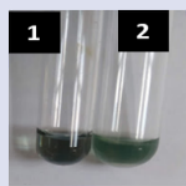

Figure 1: Phytochemical colorimetric tests of the AE and EE from $P$. hysterophorus. The phytochemical profile of the AE (1) and EE (2) of $P$. hysterophorus was evaluated by colorimetric tests. The results showed in the figure corresponds to the following colorimetric standard methods: A) Negative controls, B) Sulfuric acid, C) Modified Liebermann-Burchard, D) Salkowski, E) Baljet, F) Sodium hydroxide $10 \%$, G) Potassium permanganate, H) Foam test, I) Dragendorff, J) Wagner, K) Mayer, L) Molish, M) Ferric chloride test.

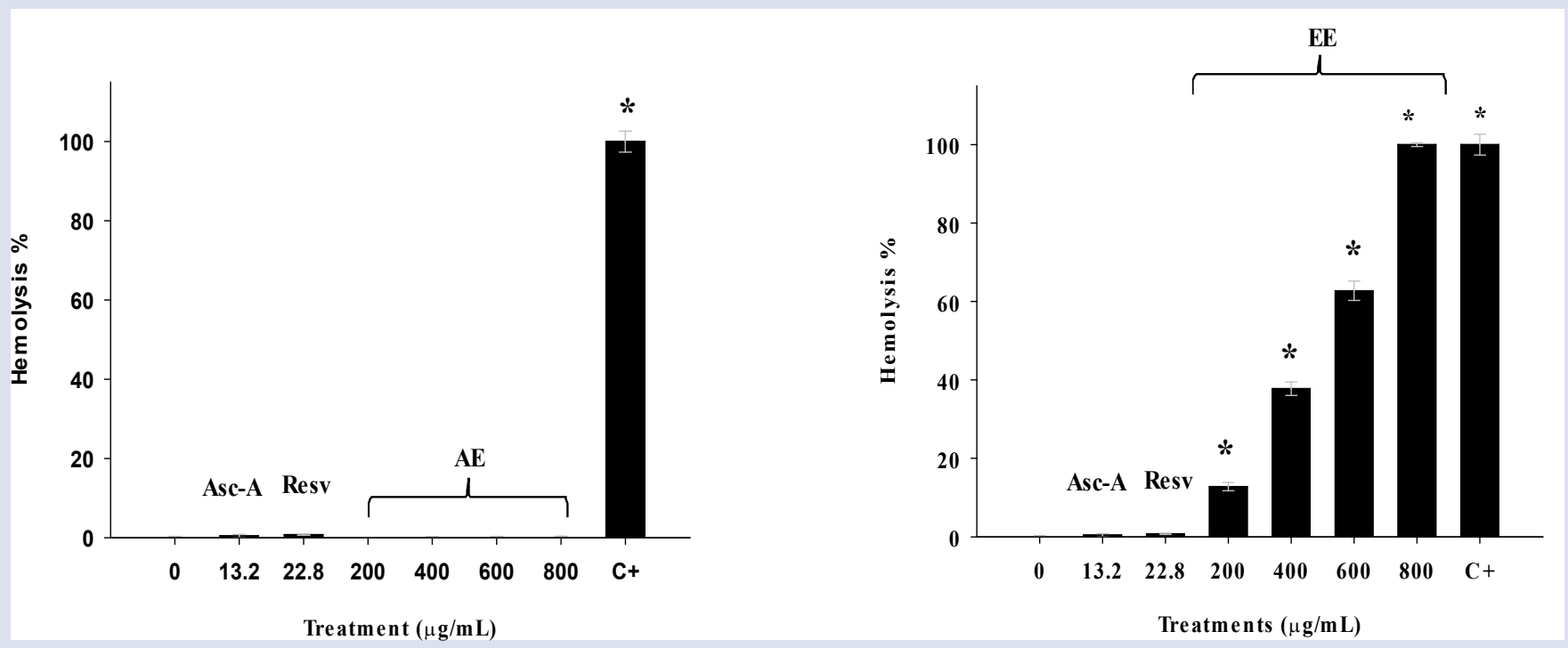

Figure 2: Hemolytic activity of AE and EE of $\boldsymbol{P}$. hysterophorus. Erythrocytes were cultured in 24-well culture plates and treated with aqueous (AE) and ethanolic (EE) crude extracts $(200-800 \mathrm{~g} / \mathrm{mL})$ from flowers of $P$. hysterophorus. In addition, Asc-A $(13.2 \mu \mathrm{g} / \mathrm{mL})$ and Resv $(22.8$ ? $\mathrm{g} / \mathrm{mL}) \mathrm{were}$ used as references, while erythrocytes treated with $\mathrm{H}_{2} \mathrm{O}$ were considerate as positive control $(\mathrm{C}+)$. Subsequently, plates were incubated at 37 o $\mathrm{C}$ for $1 \mathrm{~h}$ and hemolysis percentages were determined by measuring absorbances of supernatants at $415 \mathrm{~nm}$. The data are expressed as mean \pm SD of three replicates. $*$ ? $<0.05$ as compared with negative control.

\section{Cytotoxicity activity}

The hemolytic activity of the AE and EE on human erythrocytes was evaluated as a parameter of cytotoxicity (Figure 2). The concentrations of the $\mathrm{AE}$ and $\mathrm{EE}$ evaluated in this assay were stablished according to the concentration values $(200-800 \mu \mathrm{g} / \mathrm{mL})$ used in the antioxidant radical scavenging assays in order to compare the antioxidant and cytotoxic effects produced by the crude extracts at the same concentrations. The results exhibited the AE had not hemolytic activity in all concentrations evaluated. This could be associated with the presence of some phytochemical groups such as flavonoids, tannins, and carbohydrates. A previous study reported the presence of these three groups of metabolites in an aqueous extract from aerial parts of Sonchus oleraceaus $(1000 \mu \mathrm{g} / \mathrm{mL})$ which also exhibited a low percentage of hemolysis $(5.8 \%)^{51}$. Moreover, hydroxycinnamic acids were another phytochemical group found in our extracts of $P$. hysterophorus. These metabolites have demonstrated to induce a cytoprotective effect on human erythrocytes exposed to hemolytic agents ${ }^{52}$. Hence, it is possible 
Table 2: Phytochemicals found in the AE and EE of P. hysterophorus by RP-HPLC-MS analysis.

\begin{tabular}{|c|c|c|c|c|}
\hline No. & Retention time (min) & Mass & Compounds & Family \\
\hline \multicolumn{5}{|l|}{$\mathrm{AE}$} \\
\hline 1 & 4.007 & 317 & Myricetin & Flavonols \\
\hline 2 & 4.585 & 316.9 & Myricetin (isomer) & Flavonols \\
\hline 3 & 14.688 & 341 & Caffeic acid 4-O-glucoside & Hydroxycinnamic acids \\
\hline 4 & 15.749 & 352.9 & 1-Caffeoylquinic acid & Hydroxycinnamic acids \\
\hline 5 & 19.054 & 340.9 & Caffeic acid 4-O-glucoside (isomer) & Hydroxycinnamic acids \\
\hline 6 & 27.872 & 476.9 & Isorhamnetin 3-O-glucoside & Methoxyflavonols \\
\hline 7 & 28.052 & 476.9 & Isorhamnetin 4'-O-glucoside & Methoxyflavonols \\
\hline 8 & 30.558 & 340.8 & Tetramethylscutellarein & Methoxyflavones \\
\hline 9 & 30.890 & 460.9 & Isorhamnetin 3-O-rutinoside & Methoxyflavonols \\
\hline 10 & 31.341 & 665 & Luteolin 7-O-(2-apiosyl-6-malonyl)-glucoside & Flavones \\
\hline \multicolumn{5}{|c|}{$e$} \\
\hline 1 & 37.204 & 344.9 & Rosmanol & Phenolic terpenes \\
\hline 2 & 38.468 & 593 & Apigenin 6,8-di-C-glucoside & Flavones \\
\hline 3 & 42.015 & 801.1 & $\begin{array}{l}\text { Spinacetin 3-O-glucosyl-(1->6)-[apiosyl }(1->2)]- \\
\text { glucoside }\end{array}$ & Methoxyflavonols \\
\hline 4 & 42.388 & 315 & Protocatechuic acid 4-O-glucoside & Hydroxybenzoic acids \\
\hline 5 & 42.392 & 801.1 & $\begin{array}{l}\text { Spinacetin 3-O-glucosyl-(1->6)-[apiosyl }(1->2)] \text { - } \\
\text { glucoside }\end{array}$ & Methoxyflavonols \\
\hline 6 & 43.669 & 785.1 & Pedunculagin II & Ellagitannins \\
\hline 7 & 45.55 & 358.9 & Lariciresinol & Lignans \\
\hline 8 & 45.55 & 328.9 & 3,7-Dimethylquercetin & Methoxyflavonols \\
\hline 9 & 45.55 & 289.9 & Brevifolin carboxylic acid & Ellagitannins \\
\hline 10 & 47.801 & 299 & 4-Hydroxybenzoic acid 4-O-glucoside & Hydroxybenzoic acids \\
\hline 11 & 49.949 & 301 & Quercetin & Flavonols \\
\hline 12 & 52.462 & 313 & Cirsimaritin & Methoxyflavones \\
\hline
\end{tabular}

AE: aqueous crude extract; EE: ethanolic crude extract

that the presence of these compounds in the AE could be associated with these results.

On the other hand, the EE exhibited to increase hemolysis in a concentration dependent manner, producing total hemolysis (100\%) at the highest concentration $(800 \mu \mathrm{g} / \mathrm{mL})$. According to the results obtained from phytochemical colorimetric test, this hemolytic effect could be associated with the presence of steroids and saponins which where only found in EE. It is known steroidal compounds can produce hemolysis due to their interaction with cholesterol molecules found on membrane of erythrocytes that induces cell rupture ${ }^{53}$.

\section{ANTIOXIDANT ACTIVITY}

\section{Radical scavenging activity}

In this work, the $\mathrm{AE}$ and $\mathrm{EE}$ from P. hysterophorus were assessed for its possible antioxidant activity through scavenging radicals, using three complementary evaluations, which were TEAC, DPPH, and $\mathrm{OH}$ radical scavenging assays. It is known phytochemicals can inhibit radicals by different modes of action which can be classified into two main groups: transference of hydrogen atoms and single electron ${ }^{54}$. Hence, it is advisable to evaluate antioxidant activity of extracts with multiple assays that could contribute to understand with more details their antioxidant mechanisms ${ }^{55}$.

The evaluation of TEAC assay determines the antioxidant property of a sample to prevent the oxidation of ABTS to ABTS ${ }^{\cdot+}$ radical through the donation of protons ${ }^{54}$. In this assay, the $\mathrm{AE}, \mathrm{EE}$ and standard references were evaluated at the concentration of $1000 \mu \mathrm{g} / \mathrm{mL}(1 \mathrm{mg} / \mathrm{mL})$ following the method of expressing results by other authors ${ }^{56}$ and which allows to stablish an equivalence between the antioxidant activity of a milligram of extract and the activity of Trolox, a vitamin E analogue. The results exhibited the $\mathrm{AE}$ and $\mathrm{EE}$ had similar antioxidant activity, with TEAC
Table 3: Trolox equivalent antioxidant capacity of $A E$ and $E E$ of $P$. hysterophorus.

\begin{tabular}{cc} 
Treatment & TEAC $(\mathrm{mM} / \mathrm{mg})$ \\
C- & $0 \pm 0.004$ \\
AE & $0.112 \pm 0.001^{*}$ \\
EE & $0.112 \pm 0.013^{*}$ \\
Asc-A & $0.325 \pm 0.002^{*}$ \\
Resv & $0.197 \pm 0^{*}$ \\
\hline
\end{tabular}

C-: negative control, AE: aqueous crude extract; EE: ethanolic crude extract; Asc-A: ascorbic acid; Resv: resveratrol; $\mathbf{m M} / \mathbf{m g}$ : antioxidant activity of a millimolar concentration of Trolox equivalent to antioxidant activity of a milligram of sample. $* P<0.05$ as compared with negative control.

values of $0.112 \pm 0.001$ and $0.112 \pm 0.013 \mathrm{mM} / \mathrm{mg}$, respectively. These results were lower than those obtained by Asc-A $(0.325 \pm 0.002 \mathrm{mM} /$ $\mathrm{mg}$ ) and Resv $(0.197 \pm 0 \mathrm{mM} / \mathrm{mg})$ (Table 3).

On the other hand, in the DPPH and $\mathrm{OH}$ radical scavenging assays, the $\mathrm{AE}$ and $\mathrm{EE}$ were evaluated in a range of concentrations of $200-800$ $\mu \mathrm{g} / \mathrm{mL}$. These values were stablished based on previous studies focus on the evaluation of the antioxidant activity of different plant extracts, including Parthenium species, and which allows the comparison of the antioxidant capacity of our plant extracts with the results of other authors.

The DPPH assay determines the capacity of a sample to neutralize the $\mathrm{DPPH}^{\cdot}$ radical by the mechanism of proton-coupled electron transference ${ }^{57}$. In this assay, the $\mathrm{AE}(16.28 \pm 0.34$ to $82.34 \pm 0.64 \%)$, and the EE $(23.55 \pm 0.30$ to $88.90 \pm 0.03 \%)$ exhibited a significant increase of $\mathrm{DPPH}^{*}$ radical inhibition in a concentration dependent manner. Furthermore, the highest \% inhibition values exhibited by Asc-A and Resv were $57.32 \pm 0.65 \%$ and $94.08 \pm 0.07 \%$, respectively (Table 4). Previous studies also reported the antioxidant capacity of 
Table 4: Radical scavenging activity of AE and EE of P. hysterophorus.

\begin{tabular}{|c|c|c|c|c|c|c|c|c|}
\hline \multirow{3}{*}{ Treatment } & \multicolumn{4}{|c|}{ DPPH' inhibition \% } & \multicolumn{4}{|c|}{ OH inhibition \% } \\
\hline & \multicolumn{4}{|c|}{ Concentration $(\mu \mathrm{g} / \mathrm{mL})$} & \multicolumn{4}{|c|}{ Concentration $(\mu \mathrm{g} / \mathrm{mL})$} \\
\hline & 200 & 400 & 600 & 800 & 200 & 400 & 600 & 800 \\
\hline C- & \multicolumn{8}{|c|}{$0 \pm 0.60$} \\
\hline $\mathrm{AE}$ & $16.28 \pm 0.34^{*}$ & $44.55 \pm 0.40^{*}$ & $65.48 \pm 0.03^{\star}$ & $82.34 \pm 0.64^{*}$ & $30.98 \pm 0.20^{*}$ & $42.37 \pm 0.70^{*}$ & $52.05 \pm 0.10^{*}$ & $71.20 \pm 2.22^{*}$ \\
\hline $\mathrm{EE}$ & $23.55 \pm 0.30^{*}$ & $50.66 \pm 0.23^{*}$ & $79.48 \pm 0.51^{*}$ & $88.90 \pm 0.03^{*}$ & $23.99 \pm 1.41^{*}$ & $32.26 \pm 0.40^{*}$ & $32.36 \pm 0.50^{*}$ & $41.33 \pm 0.40^{*}$ \\
\hline Asc-A & $57.32 \pm 0.65^{\star}$ & $56.09 \pm 0.20^{*}$ & $55.24 \pm 0.30^{*}$ & $54.69 \pm 0.03^{*}$ & $35.70 \pm 0.78^{\star}$ & $39.64 \pm 0.39^{*}$ & $50.20 \pm 0.49^{*}$ & $54.54 \pm 0.49^{*}$ \\
\hline Resv & $83.20 \pm 0.11^{*}$ & $91.94 \pm 0.18^{*}$ & $93.37 \pm 0.27^{*}$ & $94.08 \pm 0.07^{*}$ & $11.49 \pm 0.40^{*}$ & $15.32 \pm 0.40^{*}$ & $12.03 \pm 0.93^{*}$ & $12.90 \pm 0.53^{*}$ \\
\hline
\end{tabular}

C-: negative control, AE: aqueous crude extract; EE: ethanolic crude extract; Asc-A: ascorbic acid; Resv: resveratrol; DPPH': 2,2-diphenyl-1-picrylhydrazyl radical; OH: Hydroxyl radical. * ? $<0.05$ as compared with negative control.

aqueous $(200 \mu \mathrm{g} / \mathrm{mL})$ and ethanolic $(250 \mu \mathrm{g} / \mathrm{mL})$ leaf extracts of $P$. hysterophorus in DPPH assay, obtaining inhibition values of $40 \%$ and $66.28 \%$, respectively ${ }^{58-59}$.

The $\mathrm{OH}$ radical scavenging assay determines the capacity of a sample to inhibit the formation of $\mathrm{OH}$ radicals generated from the $\mathrm{Fe}^{3+} /$ ascorbate/EDTA/ $\mathrm{H}_{2} \mathrm{O}_{2}$ complex and which can be neutralized by the donation of protons ${ }^{60}$. The results obtained in this assay showed that the $\mathrm{AE}$ produced a significant antioxidant effect in a concentration dependent manner $(30.98 \pm 0.20 \%-71.20 \pm 2.22 \%)$, while the $\mathrm{EE}$ exhibited a lower antioxidant activity $(23.99 \pm 1.41 \%$ to $41.33 \pm 0.41$ $\%)$. In the case of the control references, the highest antioxidant effects of Asc-A and Resv were $54.54 \pm 0.49 \%(800 \mu \mathrm{g} / \mathrm{mL})$ and $15.32 \pm 0.40 \%$ $(400 \mu \mathrm{g} / \mathrm{mL})$ respectively. These values were lower than those obtained by the $\mathrm{AE}$ at the same concentrations, while the $\mathrm{EE}$ only showed higher effects than Resv (Table 4). A previous study also reported the antioxidant activity of acetonic extract of $P$. hysterophorus stem (100 $\mu \mathrm{g} / \mathrm{mL}$ ), exhibiting about a $30 \%$ of inhibition of the $\mathrm{OH}$ radical ${ }^{18}$.

According to the results obtained in the three radical scavenging assays, the $\mathrm{AE}$ and $\mathrm{EE}$ showed the capacity to prevent the formation of radicals (ABTS and ${ }^{-} \mathrm{OH}$ ) and inhibit those already formed ( $\mathrm{DPPH}^{\circ}$ ). These results give some details about how the $\mathrm{AE}$ and $\mathrm{EE}$ of $P$. hysterophorus could perform their antioxidant effects in the organism. However, more evaluations are necessary to confirm these mechanisms. On the other hand, according to the phytochemical profile, the in vitro antioxidant activities of the $\mathrm{AE}$ and $\mathrm{EE}$ could be attributed to the different phytochemical compounds found in them such as flavonoids, tannins, coumarins, triterpenes, and carbohydrates ${ }^{7-8}$. It is known the plant crude extracts are complex mixtures of metabolites which can influence the biological activities of one another, increasing their beneficial properties for human health. One of them is the antioxidant activity that contributes to the inhibition of radicals through the donation of electrons/protons that is determined for the configuration and total number of functional groups that constitute the chemical structures of many phytochemical compounds ${ }^{12,61}$.

\section{Antioxidant enzyme activity}

It is known phytochemical compounds not only produce their antioxidant effect through the direct neutralization of radicals, but also can stimulate the activity of antioxidant enzymes such as SOD and $\mathrm{CAT}^{62}$. Currently, there are not previous reports about the influence of $P$. hysterophorus extracts on the activity of these enzymes. Hence, in this study, the effect of the AE and $\mathrm{EE}$ of P. hysterophorus in the activity of SOD and CAT was evaluated using supernatants from erythrocytes previously treated with the extracts for the hemolysis assay. Erythrocytes are cells constantly exposed to inducing factors of oxidative stress in the organism. However, these cells can regulate the oxidative stress through various antioxidant mechanisms. One of them is the antioxidant enzymatic pathway in which SOD and CAT contribute to the inhibition of ROS. The SOD enzyme produces the dismutation of the radical $\mathrm{O}^{2-}$ to $\mathrm{O}_{2}$ and $\mathrm{H}_{2} \mathrm{O}_{2}{ }^{63}$, while the CAT enzyme catalyzes the conversion of $\mathrm{H}_{2} \mathrm{O}_{2}$ to non-cytotoxic compounds such as $\mathrm{H}_{2} \mathrm{O}$ and $\mathrm{O}_{2}{ }^{64}$. For this reason, the erythrocytes represent a useful in vitro model for the study of the effect of phytochemicals on the SOD and CAT enzymes through the increase or decrease of their antioxidant activities $^{65}$.

In this study, the results exhibited that the SOD activity of erythrocytes treated with $\mathrm{AE}$ showed enzymatic activity in all concentrations evaluated but only a significant increase was produced at $600 \mu \mathrm{g} /$ $\mathrm{mL}(16.85 \pm 0.29 \mathrm{U} / \mathrm{mL})$ and $800 \mu \mathrm{g} / \mathrm{mL}(54.66 \pm 47.12 \mathrm{U} / \mathrm{mL})$, respectively. These results were lower than the obtained by Asc-A $(69.77 \pm 4.99 \mathrm{U} / \mathrm{mL})$ but similar than Resv $(53.98 \pm 3.46 \mathrm{U} / \mathrm{mL})$ at the highest concentration.

Increasing effects on SOD activity has been previously demonstrated by other plant extracts. Lee et. $a l^{66}$ reported the increase of SOD activity in vitro in V79-4 cell line (hamster lung fibroblast) cultures produced by methanolic extracts of Areca catechu var. dulcissima, Alpinia officinarum, and Paeonia suffruticosa $(100 \mu \mathrm{g} / \mathrm{mL})$, inducing percentages of increase in antioxidant enzyme activity of $45 \%, 40 \%$, and $43 \%$, respectively. Other studies have exhibited the presence of tannins and flavonoids such as isorhamnetin and luteolin in extracts from these plant species ${ }^{67-69}$. These groups of phytochemicals and similar compounds were also detected in the AE of $P$. hysterophorus and could be associated with the increase of SOD activity.

On the other hand, EE exhibited an absence of SOD activity in all concentrations (Table 5). Previous studies have reported some phytochemicals as apigenin, have the capacity to reduce SOD activity in vitro through the formation of stable complexation with metal ions $\mathrm{Cu}^{2+}$ and $\mathrm{Zn}^{2+}$, avoiding the assemble of SOD with these cofactors ${ }^{70}$. Hence, it is probably some of the phytochemicals that constitute the EE as apigenin 6,8-di-C-glucoside, could be a possible cause of this inhibitory effect in SOD. However, more studies are needed to demonstrate this effect of the EE on antioxidant enzymes.

The evaluation of CAT activity in the AE showed enzymatic activity in all concentrations but only a significant increase was produced at 400 $\mu \mathrm{g} / \mathrm{mL}(125.82 \pm 37.39 \mathrm{nmol} / \mathrm{min} / \mathrm{mL})$ and $600 \mu \mathrm{g} / \mathrm{mL}(98.79 \pm 10.90$ $\mathrm{nmol} / \mathrm{min} / \mathrm{mL}$ ). A significant increase on CAT activity produced by plant extracts was also reported by Lee $e t$. $a l^{71}$ who evaluated the effect of methanolic seed extract of Euryale ferox $(100 \mu \mathrm{g} / \mathrm{mL})$ on V79-4 cell line, obtaining an increase of $24 \%$. It has been reported the presence of tannins, flavonoids, steroids, and saponins in seed extracts of $E$. ferox ${ }^{72}$, which were also detected in the AE and EE of P. hysterophorus and could be associated with the increase of CAT activity.

Moreover, the EE also induced significant increase at $600 \mu \mathrm{g} / \mathrm{mL}$ $(151.09 \pm 41.55 \mathrm{nmol} / \mathrm{min} / \mathrm{mL})$ and $800 \mu \mathrm{g} / \mathrm{mL}(253.33 \pm 0 \mathrm{nmol} / \mathrm{min} /$ $\mathrm{mL}$ ) (Table 5 ). These effects on CAT activity produced by the EE could exhibit a correlation with the results previously obtained by the EE in the evaluation of SOD enzyme, in which non-SOD activity was detected. 
Table 5: Antioxidant enzyme activity of AE and EE from P. hysterophorus.

\begin{tabular}{llll}
\hline Treatment & $\begin{array}{l}\text { Concentration } \\
(\mu \mathrm{g} / \mathrm{mL})\end{array}$ & $\begin{array}{l}\text { Enzyme activity } \\
\text { SOD } \\
(\mathrm{U} / \mathrm{mL})\end{array}$ & $\begin{array}{l}\text { CAT } \\
(\mathrm{nmol} / \mathrm{min} / \mathrm{mL})\end{array}$ \\
\hline C- & 0 & $9.49 \pm 2.16$ & $69.73 \pm 24.10$ \\
& 200 & $10.44 \pm 8.19$ & $91.15 \pm 8.31$ \\
& 400 & $14.01 \pm 12.23$ & $125.82 \pm 37.39^{*}$ \\
$\mathrm{AE}$ & 600 & $16.85 \pm 0.29^{*}$ & $98.79 \pm 10.90^{*}$ \\
& 800 & $54.66 \pm 47.12^{*}$ & $89.98 \pm 11.63$ \\
& 200 & $0 \pm 4.46$ & $89.39 \pm 25.76$ \\
& 400 & $0 \pm 0.88$ & $64.13 \pm 26.59$ \\
EE & 600 & $0 \pm 3.89$ & $151.09 \pm 41.55^{*}$ \\
& 800 & $0 \pm 1.26$ & $253.33 \pm 0^{*}$ \\
Asc-A & 13.2 & $69.77 \pm 4.99^{*}$ & $0 \pm 3.15$ \\
Resv & 22.8 & $53.98 \pm 3.46^{*}$ & $0 \pm 2.67$
\end{tabular}

C-: negative control, AE: aqueous crude extract; EE: ethanolic crude extract; Asc-A: ascorbic acid; Resv: resveratrol; SOD: superoxide dismutase; CAT: catalase. ${ }^{*}$ ? $<0.05$ as compared with negative control.

Previous studies have shown that the SOD enzyme can react with the $\mathrm{H}_{2} \mathrm{O}_{2}$ radical producing an inhibition of the SOD enzymatic activity due to the fragmentation of the protein structure of this enzyme ${ }^{73}$. In our study, this phenomenon could be associated with a possible formation of $\mathrm{H}_{2} \mathrm{O}_{2}$ radicals produced by the interaction between the erythrocytes and the EE that could have caused the significant increase of the CAT activity due to it has been reported that an increased generation of ROS induces the activation of enzymatic enzymes ${ }^{74}$. In addition, a possible formation of ROS could be also associated the cytotoxic effects produced by the EE in the previous hemolysis assay. Hence, according to this information, we hypothesize that the EE could have induced the formation of ROS such as $\mathrm{H}_{2} \mathrm{O}_{2}$ radicals, being responsible for the inactivation of the SOD enzyme, and the significant increase on the CAT activity. However, more studies are required to demonstrate the formation of $\mathrm{H}_{2} \mathrm{O}_{2}$ radicals by the EE on erythrocytes.

On the other hand, non-activity of CAT enzyme was detected in Asc-A and Resv controls. These results could have a correlation with the results reported by Breinholt et. al ${ }^{75}$ who evaluated the CAT antioxidant activity on erythrocytes obtained from rats (Wistar rats, 8-9 weeks) which were treated with quercetin, chrysin and genistein $(0.1 \mathrm{~g}$ flavonoid $/ \mathrm{kg}$ of rat weight/14 days), obtaining a decrease of the antioxidant activity by the three compounds. According to the authors, it is probably that the antioxidant enzymes on erythrocytes could have been decreased in response to an improved antioxidant status in the cells due to the presence of these flavonoids. Hence, it is probably the Asc-A and Resv could have produced similar effects on the erythrocytes.

\section{CONCLUSION}

In the present study, the $\mathrm{AE}$ and $\mathrm{EE}$ of $P$. hysterophorus flowers showed a phytochemical profile constituted by some phytochemical groups such as flavonoids, steroids, phytosterols, saponins, coumarins, sesquiterpene lactones, tannins, and carbohydrates which are known to have diverse biological properties for human health. In addition, the RP-HPLC-MS analysis showed the presence of compounds belonged to flavonols, methoxyflavonols, flavones, methoxyflavones, hydroxycinnamic acids, phenolic terpenes, ellagitannins and lignans. The AE did not cytotoxic effect on human erythrocytes in vitro, while EE produced hemolysis in a concentration dependent manner. The $\mathrm{AE}$ and EE exhibited a strong antioxidant activity to inhibit radicals in vitro in all concentrations, and the antioxidant activity of SOD enzyme showed a significant increased by the AE, while the CAT activity was increased by the two crude extracts, in some of the concentrations evaluated. Consequently, our data advocate $P$. hysterophorus could be a promising source of phytochemicals with antioxidant activity to inhibit radicals and stimulate the activity of antioxidant enzymes on human erythrocytes.

\section{ACKNOWLEDGMENTS}

The authors are grateful to the National Council of Science and Technology (CONACYT) for the financial of the scholarship (CVU: 999325) through the program of the Master's Degree in Food Science and Technology of the Faculty of Chemistry of the Autonomous University of Coahuila, Dr. José Ángel Villarreal Quintanilla (UAAAN) for the plant identification, and Dr. Héctor Arturo Ruiz Leza for his contribution with the revision of the manuscript.

\section{REFERENCES}

1. Viennois $E$, Gewirtz AT, Chassaing B. Chronic inflammatory diseases: are we ready for microbiota-based dietary intervention? CMGH.2019;(1)61-71.

2. World Health Organization.org [https://www.who.int/news-room/ fact-sheets/detail/noncommunicable-diseases [update 2018; cited 2021 Jun 23]

3. Steven S, Frenis K, Oelze M, Kalinovic S, Kuntic M, Bayo-Jiménez $\mathrm{M}$, et. al. Vascular inflammation and oxidative stress: major triggers for cardiovascular disease. Oxid Med Cell. Longev. 2019;2019(1):1-26.

4. Gaschlera MM, Stockwell BR. Lipid peroxidation in cell death Biochem Bioph Res Co. 2018;482(3):419-25.

5. Ighodaro OM, Akinloye OA. First line defense antioxidants-superoxide dismutase (SOD), catalase (CAT) and glutathione peroxidase (GPX): Their fundamental role in the entire antioxidant defense grid. Alexandria Med J. 2018;54(4):287-93.

6. Santos-Sánchez NF, Salas-Coronado R, Villanueva-Cañongo C Hernández-Carlos B. Antioxidant compounds and their antioxidant mechanism. In: Shalaby, E. Editor. London: IntechOpen, Antioxidants. IntechOpen. 2019. Available from: https://www.intechopen.com/ books/antioxidants/antioxidant-compounds-and-their-antioxidantmechanism.

7. Ingle KP, Deshmukh AG, Padole DA, Dudhare MS, Moharil MP., Khelurkar VC. Phytochemicals: Extraction methods, identification, and detection of bioactive compounds from plant extracts. J Pharmacogn Phytochem. 2017;6(1):32-6.

8. Prakash B, Kumar A, Singh PP, Songachan LS. Antimicrobial and antioxidant properties of phytochemicals. In: Prakash B, Editor Functional and Preservative Properties of Phytochemicals. Elsevier, p. 1-45. 2020.

9. Castro-López C, Ventura-Sobrevilla JM, González-Hernández MD, Rojas R, Ascacio-Valdés JA, Aguilar-González CN, Martínez-Ávila GCG. Impact of extraction techniques on antioxidant capacities and phytochemical composition of polyphenol-rich extracts. Food Chem. 2017;15(237):1139-48.

10. Oshiade De Silva G, Theekshana Abeysundara A, Weroshana Aponso MM. Extraction methods, qualitative and quantitative techniques for screening of phytochemicals from plants. Am. J. Essent. Oil. 2017:5(2):29-32.

11. García-Pérez JV, Mulet Pons A, Carcel Carrión JA. Ultrasound-assisted extraction of natural products. Food Eng. Rev. 2011;3(2):108-20.

12. Abubakar AR, Haque M. Preparation of medicinal plants: basic extraction and fractionation procedures for experimental purposes. J. Pharm. Bioall. Sci. 2020;12(1):1-10.

13. Do QD, Angkawijaya E, Tran-Nguyen PL, Huynh LH, Soetaredjo FE, Ismadji S, Ju YH. Effect of extraction solvent on total phenol, total flavonoid content, and antioxidant activity of Limnophila aromatica. J. Food Drug Anal.2014;22(3):296-302. 
14. Prat D, Pardigon O, Flemming HW, Letestu S, Ducandas V, Isnard $P$, Guntrum E, et al. Sanofi's solvent selection guide: a step toward more sustainable processes. Org. Process Res. Dev.2013;17(2):1517-25.

15. Prat D, Hayler J, Wells A. A survey of solvent selection guides. Green Chem.2014;16(10):4546-51.

16. Saini A, Aggarwal NK, Sharma A, Kaur M, Yadav A. Utility potential of Parthenium hysterophorus for its strategic management. Adv Agric. 2014;2014(1):1-16.

17. Kumar S, Pandey S, Pandey A. In vitro antibacterial, antioxidant, and cytotoxic activities of Parthenium hysterophorus and characterization of extracts by LC-MS analysis. BioMed Research International. 2014;2014(1):1-10.

18. Ahmad J, Bagheri R, Bashir H, Baig MA, Al-Huqail A, Ibrahim MM, et al. Organ-specific phytochemical profiling and antioxidant analysis of Parthenium hysterophorus L. Biomed Res Int. 2018; 2018(1):1-10.

19. Kumar S, Mishra A., Pandey, A. Antioxidant mediated protective effect of Parthenium hysterophorus against oxidative damage using in vitro models. BMC Complem Altern M. 2013;13(120):1-9.

20. Das B, ReddyVS, Krishnaiah M, Sharma AVS, Kumar KR, Rao JV, Sridhar V. Acetylated pseudoguaianolides from Parthenium hysterophorus and their cytotoxic activity. Phytochemistry. 2007;68(1):2029-34.

21. Kumar S, Pandey S, Pandey A. In vitro antibacterial, antioxidant, and cytotoxic activities of Parthenium hysterophorus and characterization of extracts by LC-MS analysis. Biomed Res. Int. 2014.2014(1):1-11.

22. Geogervia L, Gadjalova A, Mihaylova D, Pavlov A. Achillea millefolium L. - phytochemical profile and in vitro antioxidant activity. Int Food Res J. 2015;22(4):1347-52.

23. Chen BY, Kuo CH, LiuYC, Ye LY, Chen JH, Shieh CJ. Ultrasonic-assisted extraction of the botanical dietary supplement resveratrol and other constituents of Polygonum cuspidal. J Nat Prod. 2012;75(1):1810-13.

24. Gangwar M, Kumar-Gautam M, Kumar-Sharma A, Tripathi YB, Goel RK, Nath G. Antioxidant capacity and radical scavenging effect of polyphenol rich Mallotus philippenensis fruit extract on human erythrocytes: an in vitro study. Sci World J; 2014;24(8):1-14.

25. Hatim MY, Makhawi MA. Phytochemical screening of leaves and roots of Stylochiton borumensis: a medicinal plant. Eart \& Envi Scie Res \& Rev. 2019;2(1):1-5.

26. De León-Medina JC, Sepúlveda L, Morlett-Chávez J, MeléndezRenteira P, Zugasti-Cruz A, Ascacio-Valdés J, et al. Solid-state fermentation with Aspergillus niger $\mathrm{GH} 1$ to enhance polyphenolic content and antioxidative activity of Castilla Rose (Purshia plicata). Plants. 2020; 9(1518):1-15.

27. Macías-Martínez BI, Cortés-Hernández DA, Zugasti-Cruz A, CruzOrtíz BR, Múzquiz-Ramos EM. Heating ability and hemolysis test of magnetite nanoparticles obtained by a simple co-precipitation method. JART. 2016;14(1):239-44.

28. Zugasti A, Rivera AL, Silva SY, Alfaro MA, Sierra CA. Effect of sodium dichloroacetate as single agent or in combination with cisplatin in normal and human cervical cell lines. Trop. J. Pharm. Res. 2020;19(3):467-74.

29. Arituluk ZC, Tatli-Çankaya II, Gençler-Özka NAM. Antioxidant activity, total phenolic and flavonoid contents of some Tanacetum L. (Asteraceae) Taxa growing in Turkey. FABAD J Pharm Sci. 2016;41(1):17-25.

30. Ozyurek M, Bektasoglu B, Guclu K, Apak R. Hydroxyl radical scavenging assay of phenolics and flavonoids with a modified cupric reducing antioxidant capacity (CUPRAC) method using catalase for hydrogen peroxide degradation. Anal Chim Acta. 2008;616(1):196-206.

31. Kalasevi M, Subbaiya R, Selvam M. Synthesis and characterization of silver nanoparticles from leaf extract of Parthenium hysterophorus and its anti-bacterial and antioxidant activity. Int.J.Curr.Microbiol.App. Sci. 2013;2(6):220-7.
32. Yang L, Wen KS, Ruan X, Zhao YX, Wei F, Wang, Q. Response of plant secondary metabolites to environmental factors. Molecules; 2018;23(4):1-26.

33. Ameer K, Shahbaz HM, Kwon KH. Green extraction methods for polyphenols from plant matrices and their bioproducts: a review. Compr. Rev. Food Sci. F.2017;16(1):295-315.

34. Azmir J, Zaidul ISM, Rahman MM, Sharif KM, Mohamed A, Sahena F, Jahurul MHA, Ghafoor K, Norulaini NAN, Omar AKM. Techniques for extraction of bioactive compounds from plant materials: a review. J. Food Eng.2013;117(1):426-436.

35. Zhang OW, Lin LG, Ye WC. Techniques for extraction and isolation of natural products: a comprehensive review. Chin. Med. 2018;13(20):126.

36. Hernández-Marín DA, Guevara-Lara F, Rivas-Morales C, VerduzcoMartínez JA, Galindo-Rodríguez SA, Sánchez-García E. Biological activity of Nothoscordum bivalve (L.) Britton and Parthenium incanum Kunth extracts. Indian J Tradit Know. 2018;17(4):699-706.

37. Apak R, Güçlü K, Demirata B, Özyürek M, Çelik SE, Bektaşoğlu B, Berker KI, Özyurt D. Comparative evaluation of various total antioxidant capacity assays applied to phenolic compounds with the CUPRAC assay. Molecules. 2007;12(1):1496-1547.

38. Dailey A, Vuong QV, Yildiz F. Effect of extraction solvents on recovery of bioactive compounds and antioxidant properties from macadamia (Macadamia tetraphylla) skin waste. Cogent food agric.2015;1(1):1-10.

39. Feng W, Li M, Hao Z, Zhang J. Analytical methods of isolation and identification. https://www.intechopen.com/books/phytochemicalsin-human-health/analytical-methods-of-isolation-and-identification.

40. Stalikas CD. Extraction, separation, and detection methods for phenolic acids and flavonoids. J. Sep. Sci.2007;30(1):3268-95.

41. Huaman-Castilla NL, Martínez-Cifuentes M, Camilo C, Pedreschi F, Mariotti-Celis M, Pérez-Correa JR. The impact of temperature and ethanol concentration on the global recovery of specific polyphenols in an integrated HPLE/RP process on Carménère pomace extracts. Molecules.2019;24(7):1-16.

42. Zuorro A, lannone A, Lavecchia R. Water-organic solvent extraction of phenolic antioxidants from Brewers'Spent grain. Porcesses.2019;7(126):1-11.

43. Piluzza G, Campesi G, Molinu MG, Re GA, Sulas L. Bioactive compounds from leaves and twigs of Guayule grown in a Mediterranean environment. Plants. 2002;9(442):1-17.

44. Jaiswal R, Kiprotich J, Kuhnert N. Determination of the hydroxycinnamate profile of 12 members of the Asteraceae family. Phytochemistry. 2011;72(1):781-90.

45. Landa A, Casado R, Calvo Ml. Identification and quantification of flavonoids from Chuquiraga spinosa (Asteraceae). NPC. 2009;4(10):1353-5.

46. Sen A, Turan SO, Bitis L. Bioactivity-guided isolation of antiproliferative compounds from endemic Centaurea kilae. Pharm Biol. 2017;55(1):541-6.

47. Witte S, Moco S, Vervoort J, Matern U, Martens S. Recombinant expression and functional characterization of regiospecific flavonoid glucosyltransferases from Hieracium pilosella L. Planta. 2009;229(1):1135-46.

48. Nalewajko-Sieliwoniuk E, Pliszko A, Nazaruk J, Barszczewska E, Pukszta, W. Comparative analysis of phenolic compounds in four taxa of Erigeron acris s. I. (Asteraceae). Biologia. 2019;74(1):1569-77.

49. Ascacio-Valdés JA, Aguilera-Carbó A, Rodríguez-Herrera R, AguilarGonzález C. Determination of ellagic acid in native plants from the Mexican semi-desert. Rev Mex Cienc Farm. 2013;44(2):36-40.

50. Olennikov DN, Chirikova NK, Kashchenko NI. Spinacetin, a new caffeoylglycoside, and other phenolic compounds from Gnaphalium uliginosum. Chem Nat Compd. 2015;51(6):1085-90. 
51. Dima J, Raghda L, Abdul-Jalil G. Evaluation of hemolytic and antihemolytic activity of the aerial parts of Sonchus oleraceus extracts. IJPSN. 2017;10(3):3745-51.

52. Salazar-López NJ, González-Aguilar GA, Loarca-Piña G, CincoMoroyoqui FJ, Rouzaud-Sández O, Domínguez-Avila JA, et al. Contribution and interactions of hydroxycinnamic acidsm found in bran and wholegrain sorghum (Sorghum bicolor L. Moench): Effects on the antioxidant capacity and inhibition of human erythrocytes hemolysis. Oxid Med Cell Longev. 2017; 2017(1):1-9.

53. Rodrigues-Pinto FG, Ferreira da Silva FC, de Paula-Barbosa A. Evaluation of phytochemical profile and haemolytic activity of Acacia mearnsii. BJPR; 2016;14(2):1-6.

54. Moharram HA, Youssef MM. Methods for determining the antioxidant activity: a review. Alex J Fd Sci \& Technol. 2014;11(1):31-42.

55. Bruno M, Ilardi V, Lupidi G, Quassinti L, Bramucci M, Fiorini D, et al. Composition and biological activities of the essential oil from a Sicilian accession of Prangos ferulacea (L.) Lindl. Nat Prod Res. 2019;35(5):733-743.

56. Tachakittirungrod S, Okonogi S, Chowwanapoonpohn S. Study of antioxidant activity of certain plants in Thailand: mechanism of antioxidant action of guava leaf extract. Food Chem. 2007;103(1):381-8.

57. Nenadis N, Tsimidou MZ. DPPH (2,2-di(4-tert-octylphenyl)-1picrylhydrazyl) radical scavenging mixed-mode colorimetric assay(s). In: Apak, R., Capanoglu, E., Shahidi, F, Editors. Measurement of antioxidant activity and capacity. Oxford: John Wiley \& Sons Ltd, p. 141-64; 2018.

58. Ahmad N, Fazal H, Abbasi BH, Farooq S. Efficient free radical scavenging activity of Ginkgo biloba, Stevia rebaudiana and Parthenium hysterophorous leaves through DPPH (2, 2-diphenyl-1picrylhydrazyl). Int J Phytomedicine. 2010;2(3):231-39.

59. Kalasevi M, Subbaiya R, Selvam M. Synthesis and characterization of nanoparticles from leaf extracts of Parthenium hysterophorus and its anti-bacterial activity and antioxidant activity. Int J Curr Microbiol Sci. 2013;2(6):220-7.

60. Yazdanparast $\mathrm{R}$, Ardestani A. In vitro antioxidant and free radical scavenging activity of Cyperus rotundus. J Med Food. 2007;10(4):66774.

61. Kumar S, Pandey AK. Chemistry and biological activities of flavonoids: an overview. Sci. World J.2013;2013(1):1-17.

62. Cheng YT, Lu CC, Yen GC. Phytochemicals enhance antioxidant enzyme expression to protect against NSAID-induced oxidative damage of the gastrointestinal mucosa. Mol Nutr Food Res. 2017; 61(6) [about 58 p] Available from: https://pubmed.ncbi.nlm.nih. gov/27883262/.
63. Azadmanesh J, Borgstahl GEO. A review of the catalytic mechanism of human manganese superoxide dismutase. Antioxidants.2018; 7 (2): $1-16$.

64. Kaushal J, Mehandia S, Singh G, Raina A, Arya SK. Catalase enzyme: application in bioremediation and food industry. ISBAB.2018;16 (1):192-9.

65. Cimen MYB. Free radical metabolism in human erythrocytes. Clin Chim Acta. 2008;390(1-2):1-11.

66. Lee SE, Hwang HJ, Ha JS, Jeong HS, Kim JH. Screening of medicinal plant extracts for antioxidant activity. Life Sciences. 2003;73(1):16779.

67. Peng W, Liu YJ, Wu N, Sun T, He XY, Gao YX, et al. Areca catechu L. (Arecaceae): a review of its traditional uses, botany, phytochemistry, pharmacology and toxicology. J Ethnopharmacol. 2015;164(1):34056.

68. Basri AM, Taha H, Ahmad N. A review on the pharmacological activities and phytochemicals of Alpinia officinarum (Galangal) extracts derived from bioassay-guided fractionation and isolation. Pharmacogn Rev. 2017:11(21):43-56.

69. Pan Y, Gao Z, Huang XY, Chen JJ, Geng CA. Chemical and biological comparison of different parts of Paeonia suffruticosa (Mudan) based on LCMS-IT-TOF and multi-evaluation in vitro. Ind Crops Prod. 2020;144 (1):1-9.

70. Xu Y, Xin Y, Diao Y, Lu C, Fu J, Luo L, et al. Synergistic effects of apigenin and paclitaxel on apoptosis of cancer cells. PLoS one. $2011 ; 6(12): 1-12$.

71. Lee SE, Ju EM, Kim JH. Antioxidant activity of extracts from Euryale ferox seed. Exp. Mol. Med. 2002;34(2):100-6.

72. Parray JA, Kamili AN, Hamid R, Ganai BA, Mustafa KG, Qadri RA. Phytochemical screening, antifungal and antioxidant activity of Euryale ferox - SALISB, a threatened aquatic plant of Kashmir Himalaya. J. Pharm. Res. 2011;4(7):2170-4.

73. Gottfredsen RH, Larsen UG, Enghild JJ, Petersen SV. Hydrogen peroxide induce modifications on human extracellular superoxide dismutase that results in enzyme inhibition. Redox Biol.2013;1(1):2431.

74. Sutcu R, Altuntas I, Buyukvanli B, Akturk O, Ozturk O, Koylu H, Delibas N. The effects of diazinon on lipid peroxidation and antioxidant enzymes in rat erythrocytes: role of vitamins $\mathrm{E}$ and $\mathrm{C}$. Toxicol. Ind. Health.2007;23(1):13-17.

75. Breinholt V, Lauridsen ST, Dragsted LO. Differential effects of dietary flavonoids on drug metabolizing and antioxidant enzymes in female rat. Xenobiotica, 2000;29(12):1227-40. 


\section{GRAPHICAL ABSTRACT}

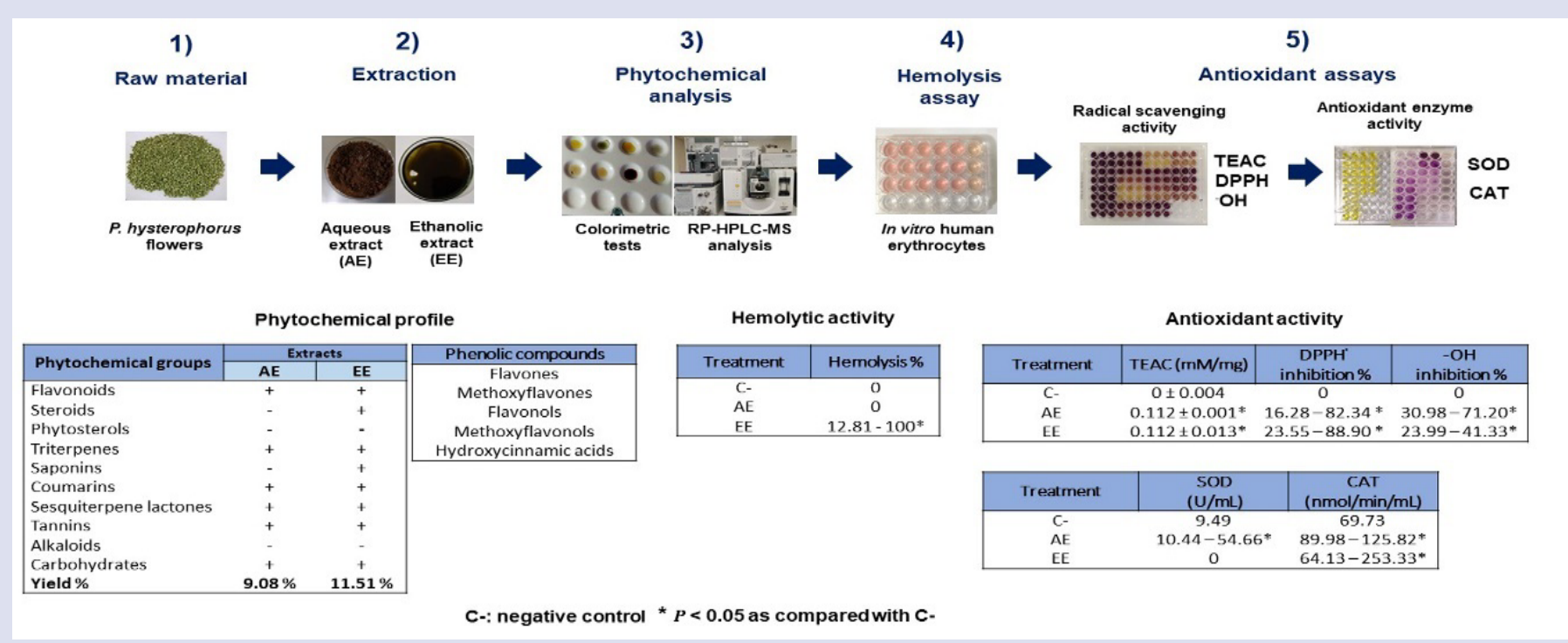

\section{ABOUT AUTHORS}

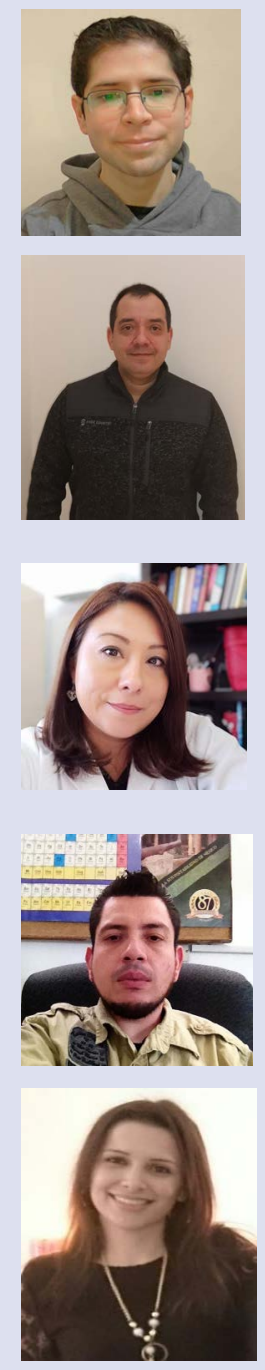

\section{Miguel Ángel Alfaro Jimenez}

Miguel Alfaro is a pharmacobiologist chemist graduated at the Autonomous University of Coahuila. Currently, he is working in a postgraduate thesis project focuses on the evaluation of the phytochemical composition and biological properties of extracts from Parthenium hysterophorus.

\section{PhD. Alejandro Zugasti Cruz}

Professor-researcher at the Faculty of Chemistry of the Autonomous University of Coahuila. $\mathrm{PhD}$. Alejandro Zugasti is a specialist in the evaluation of the pharmacological and toxicological activity of compounds of natural origin (animal poisons, plant extracts) and synthetic origin (nanomaterials).

\section{PhD. Sonia Yesenia Silva Belmares}

Professor-researcher at the Faculty of Chemistry of the Autonomous University of Coahuila. The line of research of $\mathrm{PhD}$. Yesenia Silva focuses on the phytochemical studies of indigenous medicinal plants. The studies aim to isolate and characterize natural products to formulate new ethnopharmaceutical drugs. Consequently, her research has focused on finding compounds to treat various diseases such as bacterial infections, cancer, inflammation, diabetes, and other neglected diseases.

\section{PhD. Juan Alberto Ascacio Valdés}

Professor-researcher at the Faculty of Chemistry of the Autonomous University of Coahuila. $\mathrm{PhD}$. Juan Alberto Ascacio is specialist in extraction of bioactive compounds (phytochemicals) assisted by bioprocesses, isolation, separation, purification and characterization by analytic techniques, and the evaluation of their biological potential (antimicrobial, antioxidant, and antitumor activity).

\section{PhD. Crystel Aleyvick Sierra Rivera}

Professor-researcher at the Faculty of Chemistry of the Autonomous University of Coahuila, Mexico. PhD. Crystel Sierra has a Doctorate in Immunobiology awarded by the Autonomous University of Nuevo Leon. Currently, she has published more than eighteen papers in indexed journals, whose research focuses on the evaluation of the immunomodulatory potential of natural and / or synthetic products in adjuvant therapy against cancer and / or inflammatory diseases. 